\title{
Identifying the Role of Brand Loyalty in the Relationship between Brand Awareness, Brand Association and Repurchase Intention
}

\author{
Zeki Pranata and Dudi Permana
}

\section{ABSTRACT}

\begin{abstract}
This research aims to analyze the influence of brand awareness, brand association on repurchase intention mediated brand loyalty. The object of this study was indosat ooredoo consumers, and the specified number of sampel was 120 respondents using a calculation method based on the heir formula multiplied by 5 . Purposive sampling sample withdrawal method, date collection method using questionnaire, and data analysis using Partial Least Square (PLS). The results of the study are known that brand awarness affects repurchase intention, brand assocation affects repurchase intention, brand awareness affects brand loyalty, brand assocation affects brand loyalty, and brand loyalty affects repurchase intention.
\end{abstract}

Keyword: Brand loyalty, Brand awarness, Repurchase intention, Brand association.

\author{
Submitted : January 19, 2021 \\ Published : February 12, 2021 \\ ISSN: $2507-1076$ \\ DOI: $10.24018 /$ ejbmr.2021.6.1.704 \\ Zeki Pranata \\ Universitas Mercu Buana Jakarta, \\ Indonesia. \\ (e-mail: zekipranata ${ }^{\circledR}$ gmail.com) \\ Dudi Permana* \\ Universitas Mercu Buana Jakarta, \\ Indonesia. \\ (e-mail: dudi.permana ${ }^{\circledR}$ mercubuana.ac.id) \\ *Corresponding Author
}

\section{INTRODUCTION}

The provide market in Indonesia has great potential, especially since the development of the internet has continued to increase in Indonesia. One of the companies engaged in this field is Indosat Ooredoo. PT Indosat Tbk is faced with the existing intense business competition, especially competition from similar companies, making the company even more motivated in terms of attracting consumers.

\begin{tabular}{ccc}
\multicolumn{3}{c}{ TABLE 1: TOP BRAND INDEX SIMCARD YEAR 2019 } \\
\hline Brand & TBI & Position \\
\hline Simpati & $39.5 \%$ & 1 \\
Three 3 & $14.7 \%$ & 2 \\
XL & $12.1 \%$ & 3 \\
IM3 & $9.9 \%$ & 4 \\
Axis & $6.1 \%$ & 5 \\
\hline
\end{tabular}

IM3 is only in the 4th position on the top brand index. This shows that consumer interest in repurchasing is very lacking. This statement is supported by the income of PT Indosat Tbk which decreased from $\mathrm{Rp} 29,926.1$ billion in 2017 to $\mathrm{Rp}$ $23,139.5$ billion in 2018 or $22.7 \%$. The decline in PT Indosat Tbk's revenue in 2018 was due to the decrease in sales of products offered by PT Indosat Tbk, even though in 2017 PT Indosat Tbk increased its marketing promotions to strengthen the brand itself and could not increase its income.

Companies need to pay attention to consumer behavior and what factors influence consumers in making repeat purchases, this is one way for companies to know what is needed and wanted and to provide satisfaction to consumers. Based on the results of the pre-survey on 30 consumers, there are several factors that influence the repurchase interest, including brand loyalty (73\%), brand awareness $(80 \%)$, and brand associates $(67 \%)$.

\section{LITERATURE REVIEW}

\section{A. Repurchase Intention}

High repurchase interest reflects a high level of satisfaction from consumers when deciding to adopt a product. The decision to adopt or reject a product arises after a consumer tries a product and then he likes or dislikes the product.

Repurchase interest is carried out based on the purchase experience that has been made [1]. When someone is satisfied with the purchase of a product or service, he will make a repeat purchase [2].

To measure repurchase intention in a product Basrah \& Samsul [3] suggest 4 dimensions that can be used:

1) Transactional interest can be interpreted as the tendency of consumers to always repurchase the products they have consumed.

2) Referential interest means the willingness of consumers to recommend products they have consumed to others.

3) Preferential interest related to consumer behavior to make a product the top choice.

4) Exploratory interest, related to the desire of consumers to always seek information about the products they are interested in

\section{B. Brand Loyalty}

Loyal consumers mean consumers who make repeated purchases of the brand and are not easily influenced by product characteristics, price and convenience of the users or various other attributes offered by alternative brand products.

Aaker [4] argues that brand loyalty is a very strong commitment from consumers to continue to buy or use a product in the future. With proper management and utilization, brand loyalty becomes a strategic asset for the 
company.

In measuring brand loyalty in a product, Basrah \& Samsul [3] suggests 4 dimensions, namely:

1) Cognitive loyalty related to the knowledge contained in a product such as product quality.

2) Affective loyalty shows customer satisfaction and pleasure with products from the same brand.

3) Conative loyalty, there is an attachment of customers to brands that they feel have a special warranty to repurchase.

4) Behavioral loyalty shows how regularly customers buy products from a particular brand. Customers only want to buy products from certain brands to meet their needs.

\section{Brand Awareness}

Brand awareness can be interpreted as the ability of consumers to remember a product or associate it with certain goods [5]. Another thing that Wati et al. [6] stated was that brand awareness was related to the ability of consumers or potential consumers to recognize a brand as part of the product category.

In their measurement, Putri \& Deniza [7] proposed 3 dimensions, including:

1) Brand recognition related to the ability of consumers to mention the characteristics of the brand's product.

2) Brand recall reflects what brands respondents remember after mentioning the first mentioned brand.

3) Top of mind describes the brand that the respondent first remembers or first mentioned when the person is asked about a product category.

\section{Brand Association}

Brand association is an attribute that already exists in a brand and will be greater if customers have a lot of experience dealing with the brand, which reflects the consumer bond between the brand and key product attributes such as logos, slogans, or personalities [8]. Meanwhile, Irwanti [9] explained that brand association is everything that is directly or indirectly related to consumer memory of a brand.

Permana. [10] argue that brand association has the following 4 dimensions:

1) Product association, product association is formed directly regarding the characteristics of the product or service concerned.

2) Organizational associations, including the ability of the company which is an association related to the company's expertise in producing and delivering output.

\section{ReSEARCH METHODOLOGY}

Based on existing theories and dimensions, the researcher makes a research framework.

The population that becomes the object of research is Indosat Ooredoo's consumers in West Jakarta. Due to the unknown number, researchers can use samples taken from the number of indicators multiplied by five [11]. Therefore, the sample is 120 respondents.

In this study, the authors used quantitative descriptive analysis, assisted by the IBM SPSS Statistics 23 and Partial Least Square (PLS) software.

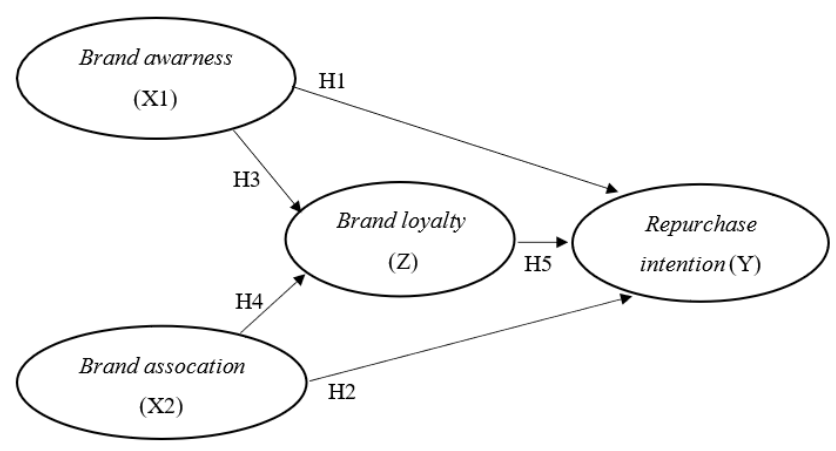

Fig. 1. Framework.

\section{RESUlT}

\section{A. Description of Respondents' Answers}

Descriptive statistics are used to interpret respondents' answers to the indicators of each variable. From the statistics obtained in this study, it can be explained that the 24 instrument items were submitted to 120 respondents

Based on the descriptions of respondents' answers, it can be seen from the lowest average value of the BA1 brand awareness variable with a value of 3.60 with the questionnaire statement "When asked to name the cellphone provider, Indosat Ooredoo is the first brand that comes to my mind".

Based on the descriptions of respondents' answers, it can be seen from the lowest average value of the BAS1 brand association with a value of 3.72 with the questionnaire statement "Indosat Ooredoo products have good application features". Based on the descriptions of respondents' answers, it can be seen from the lowest average score of BL3 brand loyalty with a value of 3.38 with a questionnaire statement "I like Indosat Ooredoo products because they have various packages and conveniences".

Based on the results of the respondent's description, if it is explained from the values of each variable indicator such as brand awareness, brand association, brand loyalty, and repurchase intention, the biggest must be maintained because it has the highest mean value, while with the lowest mean value there is at least a re-evaluation so that able to increase the mean value of the indicator which is expected to be an increase of each variable through an increase in the lowest mean value.

\section{B. Hypothesis Testing Result}

The results of hypothesis testing can be indicated by the $\mathrm{T}$ Statistic value where the recommended value must be above 1.96.

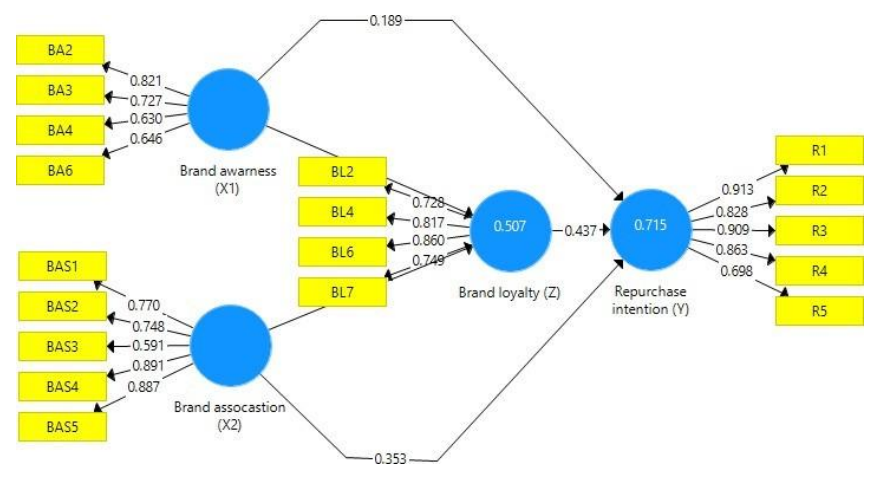

Fig. 2. Bootstrapping Results. 
1) Based on the hypothesis testing in this study, it shows the results that brand association has a positive and significant effect on brand loyalty. Because, T statistic> T table (6,364> 1,96) which can be concluded means that the influence of brand association on brand loyalty is 6,364. This means that increased brand association for Indosat Ooredoo consumers can also increase brand loyalty to Indosat Ooredoo consumers.

2) Based on the hypothesis testing in this study, the results show that the $\mathrm{T}$ statistic is greater than the $\mathrm{T}$ table (4.116> 1.96) which can be concluded that the effect of brand association on repurchase intention is 4.116 . Thus, the results of hypothesis testing in this study indicate that brand association has a positive and significant effect on repurchase intention.

3) Based on the hypothesis test in this study, it shows that the T statistic is greater than T table $(3,344>1.96)$ which can be concluded that the effect of brand awareness on brand loyalty is 3,344. Thus, the results of hypothesis testing in this study indicate brand awareness has a positive and significant effect on brand loyalty.

4) Based on the hypothesis test in this study, the results show that the $\mathrm{T}$ statistic is greater than the $\mathrm{T}$ table (2.419> 1.96) which can be concluded that the effect of brand association on repurchase intention is 2.419 . Thus, the results of hypothesis testing in this study indicate brand awareness has a positive and significant effect on repurchase intention.

5) Based on the hypothesis test in this study, it shows that the T statistic is greater than T table $(6.214>1.96)$ which can be concluded that the effect of brand loyalty on repurchase intention is 6,214 . Thus, the results of hypothesis testing in this study indicate brand loyalty has a positive and significant effect on repurchase intention.

6) Based on the hypothesis testing in this study, it shows that the T statistic is greater than T table (4.020>1.96) which can be concluded that the effect of brand loyalty on repurchase intention is 4020 . Thus, the results of hypothesis testing in this study show that repurchase intention has a positive and significant effect on repurchase intention mediated by brand loyalty.

7) Based on the hypothesis test in this study, it shows that the $\mathrm{T}$ statistic is greater than the $\mathrm{T}$ table (3.161> 1.96). Thus, the results of hypothesis testing in this study show that brand awareness has a positive and significant effect on repurchase intention mediated by brand loyalty.

\section{DISCUSSION}

\section{A. The Influence of the Brand Association on Brand Loyalty}

These results can be implemented to Indosat Ooredoo, namely if the overall brand association is able to continue to be improved through each indicator such as the product, they have is different from competitors, it will affect Indosat Ooredoo's consumer brand loyalty itself. The results of hypothesis testing in this study are supported [12] which states that brand association has a positive and significant effect on brand loyalty in increasing brand association, eating will have a direct effect on brand loyalty, this research is also supported by research conducted by [13] which states that in a study conducted in South Africa, if the increase in brand association of cosmetic users continues to be improved, it will affect the increase in cosmetic brand loyalty among consumers in South Africa.

\section{B. The Influence Brand Association on Repurchase Intention}

The results of hypothesis testing in this study can be implemented by implementing a set of brand associations towards a brand that will form a brand image, and the image is a collection and belief that arises from a person on a particular brand. The association does not only exist, but also has a level of strength. From the appearance of the brand, it will be embedded in the minds of consumers, the impressions associated with the brand will increase with the more consumer experiences in consuming it, therefore the importance of increasing the brand association is to continue to influence and increase on repurchase intention. The results of hypothesis testing in this study are supported by research conducted by [14] there is a positive and significant effect of brand association on consumer repurchase interest and according to [15] which states that brand association has a positive and significant effect on repurchase. intention.

\section{The Influence of Brand Awareness on Brand Loyalty}

Thus, the results of hypothesis testing in this study show that brand awareness has a positive and significant effect on brand loyalty, and it can be explained that if Indosat Ooredoo can increase their brand awareness through increasing each of its indicators such as continuing to carry out promotional activities through existing advertising media, Indosat Ooredoo's brand loyalty will continue to increase. The results of hypothesis testing in this study are supported by research [16] which states that there is a positive and significant effect of brand awareness on brand loyalty and according to research conducted [14] there is a positive and significant effect on brand awareness of brand loyalty, or can it be explained that if the related company is able to increase brand awareness, it will also have an effect on increasing brand loyalty.

\section{The Influence of Brand Awareness on Repurchase Intention}

Thus, the results of hypothesis testing in this study indicate brand awareness has a positive and significant effect on repurchase intention. The results of hypothesis testing in this study can be interpreted or explained if related parties can increase the existing brand awareness by paying attention to every existing indicator such as using advertising media that is widely used by Indosat Ooredoo consumers, it will affect the repurchase intention of Indosat Ooredoo consumers itself because of the media. used by related companies is also used by consumers so that the message from the advertisement used as a promotional tool arrives clearly to consumers. The results of hypothesis testing in this study are supported by research conducted by [17] which states that brand awareness has a positive and significant effect on repurchase intention, [18] which states that there is a positive and significant influence on brand equity, including namely brand awareness of repurchase intention. 


\section{E. The Influence of Brand Loyalty on Repurchase Intention}

Thus, the results of hypothesis testing in this study indicate brand loyalty has a positive and significant effect on repurchase intention. The results of hypothesis testing in this study can be interpreted if the related parties already have good brand loyalty in the minds of Indosat Ooredoo consumers and if Indosat Ooredoo increases every existing indicator continues to be improved it will affect the repurchase intention of Indosat Ooredoo consumers will also increase. The results of the hypothesis testing in this study are supported by research conducted by [19] which states that brand loyalty has a positive and significant effect on repurchase interest, as well as research conducted [20] which states that brand loyalty has a positive effect. and significant to repurchase interest.

\section{F. The Influence of Brand Association on Repurchase Intention mediated by Brand Loyalty}

Thus, the results of hypothesis testing in this study indicate that repurchase intention has a positive and significant effect on repurchase intention mediated by brand loyalty. The test results can be explained if the company already has a good brand association, then it will also increase brand loyalty, and will affect repurchase intention, or it can be explained that initially brand association affects brand loyalty and then in turn affects repurchase intention. The results of hypothesis testing in this study are supported by research conducted [21] which states that brand association to repurchase intention is mediated by brand loyalty and so is research conducted by [22] which states that brand association to repurchase intention is mediated. brand loyalty.

\section{G. The Influence of Brand Awareness on Repurchase Intention mediated by Brand Loyalty}

The results of hypothesis testing in this study can be explained that if Indosat Ooredoo already has a good brand awareness, it will increase the brand loyalty they have and in the end it will affect repurchase intention or it can be explained that initially brand awareness has an effect on brand loyalty and then ultimately affects brand awareness. The results of hypothesis testing in this study are supported by research conducted by [22], which states that brand awareness has an effect on repurchase intention mediated by the variable brand loyalty and so does research [23] that brand awareness affects repurchase intention. mediated by brand loyalty variables.

\section{CONCLUSIONS}

The conclusion is that brand awareness and brand association have an impact on increasing repurchase intention significantly, brand awareness and brand association have an impact on increasing brand loyalty significantly, and brand loyalty has an impact on increasing repurchase intention significantly.

For Indosat Ooredoo, they can re-evaluate the brand awareness itself, such as re-evaluating whether the promotional media they are using is good or not, if you have re-evaluated it, it is better to use existing influencers on Instagram or YouTube to increase Indosat Ooredoo's brand awareness. Furthermore, Indosat Ooredoo should pay more attention to whether the applications they have are easy to use and applications that do not experience system problems so that consumers feel comfortable using the applications that Indosat Ooredoo has. For further research, it can further develop variables and indicators that have not been used in this research, such as this research, such as trust, price, and convenience that can affect repurchase intention, then add retesting on the same location and object. In addition, for researchers who will conduct research in the same field and use this thesis as a reference, it is necessary to re-examine it because it does not rule out that there are inappropriate statements, because the researcher feels that there are still many shortcomings and limitations in completing this thesis.

\section{REFERENCES}

[1] Thamrin, A., \& Tantri, F. (2012). Manajemen Pemasaran. PT. Raja Grafindo Persada.

[2] Hartanto, A. (2019). Di De Mandailing Cafe Surabaya. 7(1).

[3] Basrah, S., \& Samsul, A. (2020). Pengaruh Budaya Kerja Dan Promosi Jabatan Dalam Meningkatkan Kinerja Karyawan Pada Pt. Perkebunan Nusantara Iii Labuhan Haji Labuhanbatu Utara. Ecobisma (Jurnal Ekonomi, Bisnis Dan Manajemen), 7(2), 109-124.

[4] Aaker, D. (2013). Manajemen Pemasaran Strategi (Kedelapan). Salemba Empat.

[5] Indah, N. U. R., \& Maula, R. (2018). Pengaruh Brand Equity Terhadap Keputusan Pembelian Konsumen (Studi Kasus Pada Outlet Elzatta Purwokerto) SKRIPSI Diajukan kepada Fakultas Ekonomi dan Bisnis Islam IAIN Purwokerto untuk Memenuhi Salah Satu Syarat Guna Memperoleh Gelar Sarjana Ekonomi (S. Jurnal Ekonomi \& Manajemen Bisnis, 50(1), 50-52.

[6] Wati, L., Za, S. Z., Ekonomi, F., \& Mulawarman, U. (2016). Analisis perbandingan brand equity pada produk lotion merek nivea dengan merek citra Brand equity comparison analysis on nivea brand lotion products with brand image. 1(1), 10-16.

[7] Putri, S. L., \& Deniza, M. P. (2018). Pengaruh Brand Awareness Dan Brand Loyalty Terhadap Keputusan Pembelian Produk Chicken Nugget Fiesta Di Kota Padang. Jurnal Agrica, 11(2), 70-78.

[8] Sangadji, E. M., \& Sopiah. (2013). Prilaku Konsumen: Pendekatan Praktis Disertai:Himpunan Jurnal Penelitian. Penerbit Andi.

[9] Irwanti, I. K. A. (2016). Analisis Pengaruh Brand Equity Terhadap Proses Keputusan Pembelian Pada Konsumen Pond' S Di Kota Surabaya. Jurnal Manajemen Dan Pemasaran, 1-7.

[10] Permana, D. (2018). Pengaruh Dimensi Ekuitas Merek Terhadap Keputusan Pembelian Produk Pencuci Mulut (mouthwash). Jurnal Manajemen, 22(2), 235-250.

[11] Prawira, A. (2010). Metodelogi Penelitian. PT. Grasindo.

[12] Putra, P. (2016). Pengaruh brand Association dan perceived quality terhadap brand loyalty. Universitas Trisakti.

[13] Chinomona, R., \& Maziriri, E. T. (2017). The influence of brand awareness, brand association and product quality on brand loyalty and repurchase intention: A case of male consumers for cosmetic brands in South Africa. Journal of Business and Retail Management Research, 12(1), 143-154

[14] Sari, N., \& Santika, I. (2017). Pengaruh Brand Image, Brand Association, Dan Brand Awareness Terhadap Repurchase Intention Produk Smartphone Merek Asus. E-Jurnal Manajemen Universitas Udayana, 6(8), 254093.

[15] (Maziri, 2017\& Chinomona, R. (2017). The influence of brand awareness, brand association and product quality on brand loyalty and repurchase intention: A case of male consumers for cosmetic brands in South Africa. Journal of Business and Retail Management Research, 12(1), 143-154.

[16] Hastuti, 2018 F. M. (2018). Pengaruh kesadaran merek, persepsi kualitas dan loyalitas merek terhadap minat beli ulang konsumen wardah.

[17] Anggraini, 2017. Pengaruh brand awareness terhadap minat beli ulang (Doctoral dissertation,Universitas Islam Negri "SHM" Banten)

[18] Pitaloka, I. W., \& Gumanti, T. A. (2019). The effects of brand equity on repurchase intention: The role of brand relationship quality in Muslim Wear Brand Surabaya-Indonesia. International Journal of Scientific and Technology Research, 8(1), 196-199. 
[19] Bramastha A, 2018. Dampak mediator dari brand loyalty dan brand image terhadap brand equity pada kasus bank mandiri Tbk Cabang Golden Yogyakarta.

[20] Putri, S.L., \& Deniza, M. P. (2018). Pengaruh brand awareness dan brand loyalty terhadap keputusan pembelian produk chiken nugget fiesta di kota Padang. Jurnal agrica, 11(2), 70-78.

[21] KALIMASADA, S. (2019). Pengaruh Brand Awareness Terhadap Repurchase Intention Yang Dimediasi Oleh Brand Loyalty (Studi Pada Konsumen Kalimasada Cookies Blitar). Jurnal Ilmiah Mahasiswa $F E B, 7(2)$.

[22] Santoso, V. V., \& Bunanta, F. M. (2019). The Impact of Brand Awareness, Brand Association, Brand Perceived Quality toward Repurchase Intention Mediated by Brand Loyalty in the Case of ZARA iBuss Management, $7(3)$

[23] Pradhita, A. (2016). The Influence of Brand Awareness On Repurchase Intention: The Mediating Role Of Brand Loyalty And Perceived Quality (A Study On Ready To Drink Coffee's Customers In Malang) (Doctoral dissertation, Universitas Brawijaya). 